\title{
Influence of age and maturation on perceived collective efficacy in youth basketball players
}

\section{Influencia de la edad y la maduración en la eficacia colectiva percibida en jóvenes jugadores de baloncesto}

\section{Influência da idade e da maturação na eficácia coletiva percebida em jovens jogadores de basquetebol}

\author{
Salles, William N. ${ }^{1}$, Soares, André L. A. ${ }^{1}$; Collet, Carine ${ }^{1}$, Milan, Fabrício J. ${ }^{1}$, Palheta, Carlos E. ${ }^{1}$, \\ Mendes, Felipe G. ${ }^{1}$, Kós, Luísa D. E. ${ }^{1}$, Nascimento, Juarez V. ${ }^{1}$, Carvalho, Humberto M. ${ }^{1}$ \\ ${ }^{1}$ Universidade Federal de Santa Catarina
}

\begin{abstract}
Growth and maturation impact the development of young athletes' physique and function, and may also influence their psychological and behavioral characteristics. Collective efficacy (CE), a psychological measure and potential mediator of sports performance, may be influenced by maturity status. However, there is scarce information available regarding young players' perceptions of $\mathrm{CE}$ and the relationship between the $\mathrm{CE}$ and the young athletes' maturity status. Therefore, this study examined the perceived CE variation between young basketball players accounting for the influence of chronological age and biological maturity status. The sample included fifty-seven adolescent basketball players aged 9.5 to 15.5 years. Chronological age, estimated age at peak height velocity (PHV) and CE through the Portuguese version of the Collective Efficacy Questionnaire for Sports were considered. Bayesian multilevel modeling was used to examine the athletes' perceived CE dimensions variation by age and maturity status. Overall, the adolescent basketball players' perceived CE scores were high for all dimensions: ability $(8.77 \pm 1.15)$; effort (9.20 1.03$)$; persistence $(8.87 \pm 1.18)$; preparation $(8.96 \pm 1.08)$; unity $(8.88 \pm 1.22)$. The variability estimates were very large, suggesting that the influence of maturity status on variation may be residual. There was no substantial relation between chronological age and the $\mathrm{CE}$ variation scores, although the results suggest that perceived variation was independent of chronological age variation and between players variation in maturity status. Given the small, localized sample investigated, further studies examining the relations of chronological age, maturity status, and perceived CE are suggested for better understanding the young athletes' development in sport.
\end{abstract}

Keywords: Growth and development, Sports psychology, Efficacy research.

\section{RESUMEN}

El crecimiento y la maduración afectan el desarrollo físico y la función de jóvenes atletas, y también pueden influir en sus características psicológicas y comportamentales. La eficacia colectiva (EC), una medida psicológica y un mediador potencial del rendimiento deportivo, puede verse influida por la etapa maduracional. Sin embargo, hay poca información disponible sobre las percepciones de jóvenes jugadores sobre la EC y la relación entre la CE y la 


\section{Salles, W. N.; Soares, A. L. A.; Collet, C.; Milan, F. J.; Palheta, C. E.; Mendes, F. G.; Kós, L. D. E.; Nascimento, J. V.; Carvalho, H. M.}

etapa maduracional de jóvenes atletas. Así, este estudio examinó la variación de la EC entre jóvenes jugadores de baloncesto, considerando la influencia de la edad cronológica y de la etapa maduracional. Fueron considerados y analizados, en su edad cronológica, la edad estimada en el pico de velocidad de crecimiento (PHV) y la EC, 57 jugadores de baloncesto de 9,5 a 15,5 años a través de la versión Inglesa del Cuestionario de Eficacia Colectiva para Deportes. Una serie de modelos Bayesianos de regresión lineal multinivel fue utilizada para estimar la EC percibida por los atletas de acuerdo con sus edades cronológicas y etapas maduracionales. En general, los escores de EC de los atletas fueron elevados en todas las dimensiones: habilidad $(8,77 \pm 1,15)$; esfuerzo $(9,20 \pm 1,03)$; persistencia $(8,87 \pm 1,18)$; preparación $(8,96 \pm 1,08)$; unidad $(8,88 \pm 1,22)$. Las estimaciones de variabilidad fueron muy grandes, sugiriendo que la influencia de la etapa maduracional sobre la EC es residual. No hubo relación sustancial entre la edad cronológica y los escores de EC, aunque los resultados sugieren que la EC fue independiente de la variación de la edad cronológica y de la variación en las etapas maduracionales entre los atletas. Dada la pequeña y localizada muestra investigada, se sugieren estudios adicionales que examinen las relaciones entre edad cronológica, etapa maduracional y EC para comprender mejor el desarrollo de los atletas jóvenes en el deporte.

Palabras clave: Crecimiento y desarrollo, Psicología del deporte, Estudio de la eficacia.

\section{RESUMO}

O crescimento e a maturação afetam o desenvolvimento físico e a função de atletas jovens, e também podem influenciar suas características psicológicas e comportamentais. A eficácia coletiva (EC), uma medida psicológica e potencial mediadora do desempenho esportivo, pode ser influenciada pelo estágio maturacional. No entanto, há escassa informação disponível sobre a percepção de EC de jovens jogadores e sobre e a relação entre a EC e o estágio maturacional. Portanto, este estudo examinou a variação da EC entre jovens jogadores de basquetebol, considerando a influência da idade cronológica e do estágio maturacional. Foram considerados e analisados em sua idade cronológica, na idade estimada no pico de velocidade de crescimento (PHV) e na EC, 57 atletas de basquetebol adolescentes com idades entre 9,5 e 15,5 anos por meio da versão portuguesa do Questionário de Eficácia Coletiva para Esportes. Utilizou-se uma série de modelos Bayesianos de regressão linear multinível para estimar a EC percebida pelos atletas de acordo com sua idade cronológica e estágios maturacionais. No geral, os escores de EC dos atletas foram elevados em todas as dimensões: capacidade $(8,77 \pm 1,15)$; esforço $(9,20 \pm 1,03)$; persistência $(8,87 \pm 1,18)$; preparação $(8,96 \pm 1,08)$; unidade $(8,88 \pm 1,22)$. As estimativas de variabilidade foram muito grandes, sugerindo que a influência do estágio maturacional sobre a EC seja residual. Não houve relação substancial entre a idade cronológica e os escores de EC, embora os resultados sugiram que a EC percebida tenha sido independente da variação da idade cronológica e da variação nos estágios maturacionais entre os atletas. Considerando a amostra pequena e localizada investigada, sugerem-se estudos adicionais que examinem as relações entre idade cronológica, estágio maturacional e EC para melhor entender o desenvolvimento dos jovens atletas no esporte.

Palavras-chave: Crescimento e desenvolvimento, Psicologia do esporte, Estudo da eficácia.

\section{INTRODUCTION}

Maturation is a complex and dynamic process, which involves qualitative changes that allow the athlete to progress towards higher levels of functioning (Rees et al., 2016). This process impacts the development of young athletes' physique, function, and behavior, in a way that the growth-related changes are commonly considered when interpreting functional performance. It is likely that psychological characteristics will also be impacted by maturity status (Hills and Byrne, 2010).

In team sports, interaction between athletes is a basic assumption, since peers need to rely on each other for performing certain tasks both in training and in competitions (Shearer, Holmes and Mellalieu, 2009). Hence, believing in the group's capacity is essential for a team to organize and perform the tasks necessary to achieve a certain goal (Bandura, 1997) and, consequently, to achieve a higher performance level (Myers, Paiement and Feltz, 2007).

Also known as team efficacy or team confidence, the perceived collective efficacy (CE) reflects a group's shared belief in its capacity to organize and execute some actions to achieve the goals, whether these are proposed by its members or imposed on the group (Bandura, 1997). Shared judgments about the CE of a group are important because they theoretically can influence what individuals choose to do as 


\section{Age, maturation, and collective efficacy in youth basketball}

components of the same group, how much effort they put into their actions and how persistent they find themselves when they encounter obstacles in accomplishing the task or fail to some reason (Bandura, 1997; Short, Sullivan and Feltz, 2005). In general, the higher is the perceived CE, the higher is the teams' motivational investment in their undertakings, the stronger is their staying power in the face of impediments and setbacks, and the greater is their performance accomplishments (Leo, SanchezMiguel, Sanchez-Oliva, Amado and García-Calvo, 2013; Fransen, Vanbeselaere, Cuyper, Broek and Boen, 2015; Fuster-Parra, Garcia-Mas, Ponseti and Leo, 2015).

Available data in some adult team sports settings showed that there is a positive relationship between perceived $\mathrm{CE}$ and aspects such as performance during competitions and group cohesion throughout the competitive season (Myers, Feltz and Short, 2004; Heuze, Raimbault and Fontayne, 2006; Ramzaninezhad, Keshtan, Shahamat and Kordshooli, 2009; Martínez-Santos and Ciruelos, 2013). However, studies exploring the influence of growth and maturation on the psychological dimensions such as $\mathrm{CE}$ are very limited, especially in youth sport settings.

Therefore, the sport context effects may influence in athletes' CE perception. This study focused on a single basketball program to minimize contextual influences and to better explore the growth-related effects on CE. Furthermore, information available regarding young basketball players' CE is scarce. To the best of our knowledge, there is no available information considering the relationship between the $\mathrm{CE}$ and the young athletes' maturity status in youth basketball. Thus, the aim of this study was to explore the CE variation among adolescent basketball players accounting for the interacting influence of chronological age and biological maturity status.

\section{METHOD}

\section{Study design}

We adopted an empirical and associative-predictive design, which seeks to explore possible functional relations between variables in order to estimate a prognosis for their behavior (Ato, López-García and Benavente, 2013).

\section{Participants}

Fifty-seven male adolescent basketball players aged 9.5 to 15.5 years were considered. The players were engaged in a basketball youth training program from São Paulo (Brazil) metropolitan region and competed in state level supervised by the São Paulo State Basketball Federation. Within the club, players were grouped by age category teams (one-year range per age category), where typically under- 11 and under- 12 teams trained six hours per week, and the under-13 to under-15 teams trained eight hours per week. The observed context was from an underserved city in of São Paulo metropolitan region, hence the results will likely reflect those contexts. Teams were classified in different playing levels according to their ranking during the competitive season so that they competed against other teams with similar performance levels.

\section{Procedures}

The study was approved by the Research Ethics Committee of the University of Campinas and conducted in accordance with ethical standards (Harriss and Atkinson, 2009). Athletes and their respective parents or legal guardians were informed about the study aims and procedures. They were informed that participation was voluntary and they could leave the investigation at any time. Then, both the players and their parents or legal guardians provided informed written consent. After previous authorization of teams' coaches, data were collected in the end of the competitive season. Measures were taken at the teams' training place.

Chronological age was calculated to the nearest 0.1 year by subtracting birthdate from date of data collection. The peak height velocity (PHV) was used as a maturational indicator because it is one of the most popular among researchers in this area (Malina, Rogol, Cumming, Coelho e Silva and Figueiredo, 2015). The maturity age was estimated with the maturity offset protocol (Mirwald, Baxter-Jones, Bailey and Beunen, 2002). The protocol predicts time before or after PHV based on chronological age, stature, body mass, sitting height, and estimated leg length (stature minus sitting height).

Based on maturity offset, the participants (ranging from -2.96 to +2.45 years from/to PHV) were grouped into three maturity status categories for analysis: prePHV (PHV $\leq-1.00$ year; $n=25)$, mid-PHV $(-1.00$ $<$ PHV $<+1.00$ year; $\mathrm{n}=18$ ), and post-PHV (PHV $\geq+$ 1.00 year; $\mathrm{n}=15)$. The limitations of the offset equation 


\section{Salles, W. N.; Soares, A. L. A.; Collet, C.; Milan, F. J.; Palheta, C. E.; Mendes, F. G.; Kós, L. D. E.; Nascimento, J. V.; Carvalho, H. M.}

(Malina et al., 2006; Moore et al., 2015) are assumed in the present study, hence carefulness is needed when interpreting data results.

We used the validated Portuguese version (Paes, 2014) of the Collective Efficacy Questionnaire for Sports CEQS (Short et al., 2005) to measure the teams' CE. It is a multidimensional instrument that aims to evaluate the athletes' CE in different team sports. We decided to use CEQS because it is specific to sport but not limited to just one sport, which allows a broaden comparison of CE levels within and across many sports (Short et al., 2005). This questionnaire consists of 20 questions divided into five factors: ability, effort, persistence, preparation, and unity. Ability represents how much the athletes believe they have the ability to perform the necessary actions during a match or competition; effort comprises the athletes' beliefs about overcoming adverse situations; persistence refers to the overcoming of specific situations while the game takes place; preparation reflects the athletes' belief in the ability to perform necessary pre-match behaviors that are fundamental to the group's performance, such as physical, mental, and strategic readiness; unity represents the team's belief to resolve conflicts and maintain positive attitudes and effective communication (Paes, 2014). The CEQS' general and dimension-specific scores are obtained from a tenpoint scale $(1=$ "not at all confident" to $10=$ "extremely confident"). All of the subscales are correlated with each other and with the total score (Short et al., 2005; Paes, 2014).

\section{Statistical analysis}

Descriptive statistics for chronological age, maturity offset, and CE were estimated. Subsequently, a series of Bayesian multilevel linear regression models were fitted to explore variation of players' perceived CE by maturity status, as well as examining the influence of age.

We assumed players (level-1) nested by somatic maturity status category (level-2). A null model (varying intercept model), the simplest two-level model which includes only the random parameters, was initially used to measure the proportion of total variance which fell between-maturity status (i.e., variance partition coefficient). As chronological age varied substantially between players in the present sample, and within each somatic maturity status category, we added the players' chronological age (centered at the grand mean) to the null models (allowing for the intercept to vary randomly at both level-1 and level-2).

We used weakly informative priors, normal $(0,50)$ for population level effects, and Cauchy priors $(0,1)$ for group-level effects. The choice of priors was made to allow the estimates to be based on the data information, as well as for convenience to regularize chains convergence. We ran four chains for 2000 interaction with a warm-up length of 1000 interaction to ensure convergence of the chains. The convergence of the Markov chains was examined by visual inspection of the trace-plots. We used posterior predictive checks to confirm that we did not omit relevant interactions (Gelman et al., 2013).

The models were implemented via Markov Chain Monte Carlo (MCMC) simulation using Hamiltonian Monte Carlo and its extension, the No-U-Turn Sampler. The MCMC simulations were implemented by using Stan probabilistic programming language (Stan Development Team, 2015), obtained using brms package (Bürkner, 2017) available as a package in the $\mathrm{R}$ statistical language (R Core Team, 2015).

\section{RESULTS}

The descriptive statistics of youth basketball players for the total sample and grouped by maturity status are summarized in Table 1. Overall, the players' CE scores were high for all dimensions: ability $(8.77 \pm 1.15)$; $\quad$ effort $\quad(9.20 \pm 1.03)$; $\quad$ persistence (8.87 \pm 1.18$)$; preparation $(8.96 \pm 1.08)$; unity $(8.88 \pm 1.22)$. Variance partition coefficients were consistently higher than 0.05 when considering nesting by maturity status (range between 0.11 to 0.33 ). However, the variability estimates were large, suggesting that the influence of maturity status may be residual.

Table 2 summarizes the multilevel models including chronological age as population level-effects. There was no substantial relation between chronological age and the CE scores, although the results suggest that perceived $\mathrm{CE}$ was independent of chronological variation and between players variation in maturity status. 


\section{Age, maturation, and collective efficacy in youth basketball}

Table 1. Descriptive statistics (mean and standard deviation) for the all sample and for players in each estimated maturity status category

\begin{tabular}{lccccc}
\hline & $\begin{array}{c}\text { All sample } \\
(\mathrm{n}=58)\end{array}$ & $\begin{array}{c}\text { Pre-PHV } \\
(\mathrm{n}=25)\end{array}$ & $\begin{array}{c}\text { Circum-PHV } \\
(\mathrm{n}=18)\end{array}$ & $\begin{array}{c}\text { Post-PHV } \\
(\mathrm{n}=15)\end{array}$ & $\begin{array}{c}\text { Variance partition } \\
\text { coefficient }\end{array}$ \\
\hline Chronological age, yrs & $13.79(1.50)$ & $11.81(0.88)$ & $13.31(0.72)$ & $15.25(0.81)$ & \\
Maturity offset, yrs & $0.47(1.35)$ & $-1.53(0.53)$ & $0.08(0.56)$ & $1.84(0.54)$ & \\
Collective efficacy & & & & & \\
Ability & $8.77(1.15)$ & $9.50(0.58)$ & $8.88(1.08)$ & $8.31(1.25)$ & $0.33(0.00$ to 0.78$)$ \\
Effort & $9.20(1.03)$ & $9.68(0.54)$ & $9.18(1.12)$ & $9.01(1.06)$ & $0.15(0.00$ to 0.65$)$ \\
Persistence & $8.87(1.18)$ & $9.23(0.95)$ & $8.99(1.07)$ & $8.58(1.37)$ & $0.11(0.00$ to 0.54$)$ \\
Preparation & $8.96(1.08)$ & $9.50(0.62)$ & $9.09(1.03)$ & $8.58(1.19)$ & $0.26(0.00$ to 0.75$)$ \\
Unity & $8.88(1.22)$ & $9.43(0.75)$ & $9.05(1.28)$ & $8.43(1.22)$ & $0.21(0.00$ to 0.67$)$ \\
\hline
\end{tabular}

Table 2. Multilevel regression models for analysis of covariance considering nesting by maturity status (at level-2) and controlling chronological age (grand mean centered at 13.79 years)

\begin{tabular}{|c|c|c|c|c|c|}
\hline & \multicolumn{2}{|c|}{$\begin{array}{l}\text { Population level effects } \\
\text { (95\% confidence interval) }\end{array}$} & \multicolumn{3}{|c|}{$\begin{array}{c}\text { Group level effects } \\
\text { ( } 95 \% \text { confidence interval) }\end{array}$} \\
\hline & Intercept & Age & $\begin{array}{l}\text { Level-1 standard } \\
\text { deviation }\end{array}$ & $\begin{array}{l}\text { Level-2 standard } \\
\text { deviation }\end{array}$ & $\begin{array}{c}\text { Variance partition } \\
\text { coefficient }\end{array}$ \\
\hline \multicolumn{6}{|c|}{ Collective efficacy } \\
\hline Ability & $8.80(8.21$ to 9.45$)$ & $-0.23(-0.51$ to 0.08$)$ & $1.11(0.92$ to 1.35$)$ & $0.52(0.02$ to 2.15$)$ & 0.18 (0.00 to 0.72$)$ \\
\hline Effort & $9.24(8.39$ to 10.24$)$ & $-0.01(-0.26$ to 0.31$)$ & 1.06 (0.88 to 1.28$)$ & $0.69(0.02$ to 2.99$)$ & 0.30 (0.00 to 0.85$)$ \\
\hline Persistence & $8.89(8.18$ to 9.72$)$ & $-0.13(-0.42$ to 0.21$)$ & 1.21 (1.00 to 1.47$)$ & $0.59(0.02$ to 3.12$)$ & 0.19 (0.00 to 0.82$)$ \\
\hline Preparation & 8.97 (8.29 to 9.64$)$ & $-0.20(-0.46$ to 0.12$)$ & 1.07 (0.89 to 1.29$)$ & $0.46(0.01$ to 1.98$)$ & 0.16 (0.00 to 0.70$)$ \\
\hline Unity & 8.87 (8.15 to 9.62$)$ & $-0.19(-0.44$ to 0.18$)$ & $1.22(1.01$ to 1.50$)$ & $0.54(0.02$ to 2.16$)$ & 0.16 (0.00 to 0.67$)$ \\
\hline
\end{tabular}

\section{DISCUSSION}

This study examined the CE variation between players considering the influence of chronological age and biological maturity status. Results suggest that the players had a positive perception of theirs and team's efficacy, regardless chronological age and maturity status (and its growth-related characteristics, i.e., size and function).

The CE scores were high for all dimensions in the present sample, showing that the participants perceived the importance of mutual aid spirit. This interdependence in team sports also exhibit emergent collective behavioral tendencies that differ from the sum of individual aggregated performances (Duarte, Araújo, Correia and Davids, 2012). Perceiving the confidence of colleagues and trusting them can improve the relationships within the team members, facilitate the achievement of higher performance levels, and lead to success (Myers et al., 2004; Martínez-Santos and Ciruelos, 2013).

Maturity-associated variation among individuals of the same chronological age is often considerable, particularly during pubertal development in adolescence (Mirwald et al., 2002; Malina et al., 2015). Specifically, among adolescent basketball players, there is substantial variation in body size and 


\section{Salles, W. N.; Soares, A. L. A.; Collet, C.; Milan, F. J.; Palheta, C. E.; Mendes, F. G.; Kós, L. D. E.; Nascimento, J. V.; Carvalho, H. M.}

function, particularly within a youth basketball team (Carvalho, Gonçalves, Collins and Paes, 2017), which may alter the perception about one's own abilities and limitations and interfere in perceived CE. However, regarding biological characteristics, the present results showed, at best, residual variation associated to somatic maturity status, even when considering the within-group variability in chronological age.

In fact, many factors may also influence the perceived $\mathrm{CE}$, such as communication and cultural differences (Bell and Riol, 2017), cohesion (Heuze et al., 2006; Leo et al., 2013), and confidence (Fransen et al., 2015; Fransen, Mertens, Feltz and Boen, 2017). Hence, in young basketball players the $\mathrm{CE}$ may be more associated to contextual factors and/or psychological factors than to biological determinants, which suggests additional studies that better explore such factors.

Although it contributes to a broader understanding of the relationship between age, maturation, and $\mathrm{CE}$, this study has some limitations. Firstly, we recognize that the small and specific sample of investigated athletes may reflect particular characteristics of the observed context and may limit the generalization to other youth sport contexts. Additionally, we present a descriptive cross-sectional design, which may not properly consider other personal (e.g.: maturational changes and $\mathrm{CE}$ variation throughout the season time) and environmental factors (e.g.: training workload; influence of the coach; characteristics of the opponents; requirements and formats of the competitions) that could affect the relationship between age, maturity, and $\mathrm{CE}$. In this sense, we believe that a longitudinal study design could provide deeper and more accurate insights about these topics (Fransen et al., 2017).

\section{PRACTICAL APPLICATIONS}

This study adds to the need of considering interactions between growth and psychological characteristics and behaviors of young basketball players. Given the CE variability associated with the maturation stage found in the present study, future studies may need to incorporate biological dimensions of maturation, as well as to include physiological interpretations to have a holistic interpretation of the young athletes' development. In this sense, we hope that our findings stimulate additional studies in the field that consider these multidimensional characteristics and explore other samples of young athletes in different team sports.

Because CE can increase the teams' motivational investment in their tasks and the resilience to overcome obstacles (Bandura, 1997), it is important that coaches keep working to increase the overall team's confidence in order to develop ability, effort, persistence, preparation, and unity to foster the preparation of confident and winning basketball players. At the same time, coaches must accompany how variables such as age and maturity status interfere in the development of CE in their teams, in a way that the planned interventions respect the athletes' developmental stages and contribute to their balanced physical and psychological development. Finally, we also expect that both coaches and youth sport administrators work together to structure competitive environments that respect the athletes' developmental stages and contribute to increase and/or to sustain their CE levels.

\section{Acknowledgements}

WNS, ALAS and CEP were supported by grants from the Coordenação de Aperfeiçoamento de Pessoal de Nível Superior (CAPES). FJM and LDEK were supported by grants from the Conselho Nacional de Desenvolvimento Científico e Tecnológico (CNPq). This study was partially supported by the Federação Catarinense de Basketball (Basketball Federation of Santa Catarina).

\section{REFERENCES}

1. Ato, M., López-García, J. J. and Benavente, A. (2013). Un sistema de clasificación de los diseños de investigación en psicología. Anales de Psicología, 29(3), DOI: 10.6018/analesps.29.3.178511

2. Bandura, A. (1997). Self-efficacy: the exercise of control. New York: W. H. Freeman and Company.

3. Bell, R. and Riol, C. F. (2017). The impact of cross-cultural communication on collective efficacy in NCAA basketball teams. International Journal of Cross Cultural Management, 17(2), 175-195. DOI: $10.1177 / 1470595817702678$ 


\section{Age, maturation, and collective efficacy in youth basketball}

4. Bürkner, P.-C. (2017). brms: An R Package for Bayesian Multilevel Models Using Stan. Journal of Statistical Software, 80(1), 1-28. DOI: 10.18637/jss.v080.i01

5. Carvalho, H. M., Gonçalves, C. E., Collins, D. and Paes, R. R. (2017). Growth, functional capacities and motivation for achievement and competitiveness in youth basketball: an interdisciplinary approach. Journal of Sports Sciences, 36(7), 742-748. DOI: 10.1080/02640414.2017.1340654

6. Duarte, R., Araújo, D., Correia, V. and Davids, K. (2012). Sports teams as superorganisms: implications of sociobiological models of behaviour for research and practice in team sports performance analysis. Sports Medicine, 42(8), 633-642. DOI: 10.1007/BF03262285

7. Fransen, K., Mertens, N., Feltz, D. L. and Boen, F. (2017). "Yes, we can!" review on team confidence in sports. Current Opinion in Psychology, $\quad 16 \quad 98-103 . \quad$ DOI: 10.1016/j.copsyc.2017.04.024

8. Fransen, K., Vanbeselaere, N., Cuyper, B. d., Broek, G. V. and Boen, F. (2015). Perceived sources of team confidence in soccer and basketball. Medicine \& Science in Sports \& Exercise, 47(7), 1470-1484. DOI: 10.1249/MSS.0000000000000561

9. Fuster-Parra, P., Garcia-Mas, A., Ponseti, F. J. and Leo, F. M. (2015). Team performance and collective efficacy in the dynamic psychology of competitive team: a Bayesian network analysis. Human Movement Science, 40 98-118. DOI: 10.1016/j.humov.2014.12.005

10. Gelman, A., Carlin, J. B., Stern, H. S., Dunson, D. B., Vehtari, A. and Rubin, D. B. (2013). Bayesian Data Analysis, Third Edition (Boca Raton, FL: Chapman \& Hall/CRC Press.

11. Harriss, D. J. and Atkinson, G. (2009). International Journal of Sports Medicine - ethical standards in sport and exercise science research. International Journal of Sports Medicine, 30(10), 701-702. DOI: $10.1055 / \mathrm{s}-0029-1237378$

12. Heuze, J.-P., Raimbault, N. and Fontayne, P. (2006). Relationships between cohesion, collective efficacy and performance in professional basketball teams: An examination of mediating effects. Journal of Sports Sciences, 24(1), 59-68. DOI: 10.1080/02640410500127736

13. Hills, A. P. and Byrne, N. M. (2010). An overview of physical growth and maturation. Medicine and Sport Science, 55 1-13. DOI: 10.1159/000321968

14. Leo, F. M., Sanchez-Miguel, P. A., SanchezOliva, D., Amado, D. and García-Calvo, T. (2013). Analysis of cohesion and collective efficacy profiles for the performance of soccer players. Journal of Human Kinetics, 39 221-229. DOI: 10.2478/hukin-2013-0085

15. Malina, R. M., Claessens, A. L., Van Aken, K., Thomis, M., Lefevre, J., Philippaerts, R. and Beunen, G. P. (2006). Maturity offset in gymnasts: application of a prediction equation. Medicine \& Science in Sports \& Exercise, 38(7), 1342-1347. DOI: 10.1249/01.mss.0000227321.61964.09

16. Malina, R. M., Rogol, A. D., Cumming, S. P., Coelho e Silva, M. J. and Figueiredo, A. J. (2015). Biological maturation of youth athletes: assessment and implications. British Journal of Sports Medicine, 49(13), 852-859. DOI: 10.1136/bjsports-2015-094623

17. Martínez-Santos, R. and Ciruelos, O. (2013). Collective efficacy, cohesion and performance in spanish amateur female basketball. Revista de Psicología del Deporte, 22(1), 235-238. DOI: 2013-08789-033

18. Mirwald, R. L., Baxter-Jones, A. D. G., Bailey, D. A. and Beunen, G. P. (2002). An assessment of maturity from anthropometric measurements. Medicine \& Science in Sports \& Exercise, 34(4), 689-694. DOI: 10.1097/00005768-20020400000020

19. Moore, S. A., McKay, H. A., Macdonald, H., Nettlefold, L., Baxter-Jones, A. D., Cameron, N. and Brasher, P. M. (2015). Enhancing a Somatic Maturity Prediction Model. Medicine \& Science in Sports \& Exercise, 47(8), 1755-1764. DOI: 10.1249/MSS.0000000000000588

20. Myers, N. D., Feltz, D. L. and Short, S. E. (2004). Collective efficacy and team performance: a longitudinal study of collegiate Football teams. Group Dynamics: Theory, Research, and Practice, 8(2), 126-138. DOI: 10.1037/10892699.8.2.126 
21. Myers, N. D., Paiement, C. A. and Feltz, D. L. (2007). Regressing team performance on collective efficacy: considerations of temporal proximity and concordance. Measurement in Physical Education and Exercise Science, 11(1), 1-24. DOI: $10.1080 / 10913670709337009$

22. Paes, M. J. (2014). Validação do Collective Efficacy Questionnaire for Sports (CEQS) para atletas brasileiros. (Masters in Physical Education, Dissertation), Federal University of Paraná, Curitiba.

23. R Core Team. (2015). R: A Language and Environment for Statistical Computing. Retrieved from http://www.R-project.org/

24. Ramzaninezhad, R., Keshtan, M. H., Shahamat, M. D. and Kordshooli, S. S. (2009). The relationship between collective efficacy, group cohesion and team performance in professional Volleyball teams. Brazilian Journal of Biomotricity, 3(1), 31-39.

25. Rees, T., Hardy, L., Güllich, A., Abernethy, B., Côté, J., Woodman, T., . . . Warr, C. (2016). The Great British Medalists Project: A Review of Current Knowledge on the Development of the World's Best Sporting Talent. Sports Medicine, 46(8), 1041-1058. DOI: 10.1007/s40279-016$0476-2$

26. Shearer, D. A., Holmes, P. and Mellalieu, S. D. (2009). Collective efficacy in sport: the future from a social neuroscience perspective. International Review of Sport and Exercise Psychology, 2(1), 38-53. DOI: 10.1080/17509840802695816

27. Short, S. E., Sullivan, P. and Feltz, D. L. (2005). Development and preliminary validation of the Collective Efficacy Questionnaire for Sports. Measurement in Physical Education and Exercise Science, 9(3), 181-202. DOI: 10.1207/s15327841mpee0903_3

28. Stan Development Team. (2015). Stan: A C++ Library for Probability and Sampling. Retrieved from http://mc-stan.org/ 